\title{
A Study on the awareness of road safety for trucks transportation in Peninsular Malaysia
}

\author{
Lee Leong Jie ${ }^{1}$, Choo Wern Kern ${ }^{1}$, and Bahri Mahmud ${ }^{1 *}$ \\ ${ }^{1}$ Faculty of Business and Information Science, UCSI University, Jalan Menara Gading, 56000 Cheras, Kuala Lumpur, Malaysia.
}

\begin{abstract}
Safety is the first priority during the process of transportation as an accident occurs will cause a person's life or long-term injury. This study identifies the awareness of road safety for trucks transportation in Peninsular Malaysia that highlight the factor of causing drivers not aware about the road safety for trucks transportation in Peninsular Malaysia which include driver behaviour, attitude and human error, surrounding environment, government legislative and distracted driving. Qualitative research approach is adopted in this study and in-depth interview was conducted to gather the data among the selected trucks operations company in Peninsular Malaysia. The finding show that speed performance results the safety procedure, the company greediness for small gains or profits results the awareness of safety their employees, the government's legislation punishment is not very effective and also the employees lack of understanding on safety precaution results in their own risk. Therefore, Driver Behaviour, Attitude and Human Error, surrounding Environment, Government Legislative as well as Distracted Driving and Tracking are the important factor that cannot be neglected.
\end{abstract}

\section{INTRODUCTION}

Transportation is means by of moving of goods and passengers from one location to another location which have include land, air, maritime, pipeline and space transport. In addition, transportation is very important and it is a fundamental for every business.

The accidents occur all too frequently especially for vehicles that carry heavy goods such as lorries with trailers drivers are having an irresponsible behaviour, not respecting of the loading regulations and the highway code as well as the obligation for drivers to adapt their speed which affects stopping distances to the traffic and weather conditions [1].

In Malaysia, according to the statistics by the Malaysian Institute of Road Safety Research, more than $80 \%$ of traffic accidents are caused by human error rather than faulty vehicle or road conditions. Therefore, road users have to take responsible for their own safety during driving [2]. A truck must travel under the control speed because trucks vehicles need a longer stopping distance and other road users may misjudge the speed. This could also causes the trucks to overturn more likely to lose control of the vehicles on a curve or cornering [3].

Rainfall has a higher frequency number of weatherrelated accidents and higher opportunities to cause traffic congestion. Rain can makes the road slippery where the friction between the tyre and road has loss that causes the trucks unable to break on time and causes accident. Not only that, rain will decrease the visibility of the driver that causes the driver hard to drive on the road [4]. Besides that, high wind in the rural area, it may affect a vehicle's directly by obstruction dangerous being present in the road such as fallen trees or walls [5].

The death car accident in Malaysia is serious [6]. The efficiency of the government has a significant impact and based on the competitiveness of a country and its economic growth [7]. Although the laws of Malaysia are very strict but it still has many people drink and drunk driving. The attention and the right effort has designed to reduce the number of drivers who unsafe driving or insecure because of the effects of alcohol [8].

In Malaysia laws, it is illegal for drivers to texting while driving and use mobile phones. Malaysia laws state that was illegal when the driver are hand held, but it doesn't state the driver not allow using phone with hand free [9]. So it has become a targeted topic, the traffic police does not have the right to catch the drivers that are driving but it is hand free or using a material to hold the smart phone. This problem can be solve by the government where the laws must state clearly or changes to decrease the accident amount and make the driver more focus on driving especially for truck driver. The truck driver driving while using smart phone is very dangerous as it may harm other people in the term of accident.

Song is an application to keep driver awake when driving in the journey but singing while driving will make the driver mental unable to focus on the road especially truck driver [10]. Besides that, the digital advertisement signal board will cause dazzling to truck driver because light is too strong and some truck driver can't afford the strong light suddenly irradiate to the eyes especially driving at night [11].

\footnotetext{
*Corresponding author's e-mail: bahri@ucsiuniversity.edu.my
} 
The installation of a GPS device for tracking in a vehicle will cause the processor at the central location to collect information about the location of the vehicle and use that information to determine the location of the vehicle at any given time and able to determine the drivers driving speed where calculate by the time reach to the destination by the driver.

There are several types of trucks such as 20 foot lorry and 40 foot lorry used in Peninsular Malaysia as a transportation of goods and passengers vehicles. The road safety for trucks transportation is not just only focusing on the transportation journey but also the inbound and outbound of logistics and even during the parking of a truck. Therefore, this study aims to identify the awareness of safety for trucks transportation and determinant the operation performance of trucks drivers in the Peninsular Malaysia logistic industry.

\section{METHODOLOGY}

In this study, qualitative research by held in-depth interview with individual participants for data collection in order to explore the views, belief, motivate and experience of individual participant. There are two types of interview conducted that is one-to-one interview also known as the in-depth interview and the focus group discussion that is an interview with a group of people [12].

\subsection{Hypothesis}

H1: Speed performance results the safety procedure.

H2: $\quad$ Company greediness for small gains or profits results the awareness of safety their employees. H3: Government's legislation punishment is not very effective.

H4: $\quad$ Employees lack of understanding on safety precaution results in their own risk.

\subsection{Data Collection Method}

The most common data collection method that been used for qualitative research method are the in-depth interviews and the focus group. According to Bristish Dental Journal 2008, in-depth interviews are the best choice in term to start with questions with participants where they can easily answer and then proceed with more difficult or sensitive topics [13]. In-depth interviews are used to collect data for the optimal choice of individual personal history, by exploring and experience, the point of view, especially in sensitive topic.

\subsection{Sampling Design}

\subsubsection{Sampling Unit}

Sampling unit is used as a respondent to observe and target population such as managers. The company managers will be the targeted population in this survey that working in the company with trucks operations in Peninsular Malaysia.

\subsubsection{Sampling Element}

The respondents that been chosen for the survey are managers who are operating in the company with trucks operations in Peninsular Malaysia. The respondents that been targeted are from different company from Peninsular Malaysia which means the respondents may be from different company manager.

\subsubsection{Sampling Technique}

Non-probability sampling can be used as the sampling technique in this research project, because nonprobability sampling does not select a random sample from the population of interest. It is used to decide which elements are included in the sample.

Judgment sampling will be used in this research where it is a non-probability sampling technique [14]. Judgment sampling basically researcher select the specific respondents who have the knowledge, perceptions, attitudes and experience in the field of study [15].

\subsubsection{Sampling Location}

The interview has been allocated on the companies which obtain trucks in their company within the Peninsular Malaysia.

\subsubsection{Sampling Size}

A total of 3 interviews to the different company focus on the KL area Company are considered in this study, due to the different area and different location of company [16].

\subsection{Research Instrument}

The research instrument used was a set of designed questions based on different articles on the topic and discussions with different people in the field. During the preparation of the questionnaire will be ask during the interview, structured and open-ended option were provided to accommodate to free view regarding the topic or issue. In this manner, the instrument enables to collect valid response from the interviewees. In the end, it encourages open response to the issue or topic discussed. The designed questionnaires are:

Q1. Do you think safety awareness on the road is important or not? Why?

Q2. Does your company prepare a proper training to your workers and that they are aware of their conditions during the work?

Q3. Once your company has established the safety awareness activity, how would your company maintain it and let the workers apply it?

Q4. Does your company follow the law and regulation provided by the government such as correctly 
wear the seat belt while driving, the lorry does not overload and at a limit height?

Q5. What is the safety-first attitude or action in your company? How does your company remind your workers to apply the safety-first attitude or action? (e.g giving warning letter)

Q6. If the delivery will not make it on time due to unexpected delays such as heavy rain and cause traffic jam. Who is going to take the responsible by resolving it?

Q7. In term to improve customer's satisfaction and reliability of customer, does your company strictly stick to your clients instructions and carry out further quality assurance measures?

Q8. Road safety is very important especially for trucks transportation, how often does your company perform maintenance for each of the trucks in your company?

Q9. Does your company hire a co-driver to support the driver during a long driving distance beside the driver to prevent accident to happen such as sleepiness during driving?

Q10. Does your company provide any equipment for your workers/drivers to protect their health such as sunglasses or tinted glasses while driving to protect their vision? If no, why?

Q11. With the usage of smartphone such as GPS or radio will distract the driver while driving. Does your company allow your company's truck drivers to use the smartphone's GPS or listen to the radio while driving?

Q12. In the rural areas, it seldom mentions about the speed limit. Does your company set a rule and regulation for the limit for the drivers to drive in the rural area? If no, why? If yes, please refer to question 13.

Q13. If the driver reckless driving in the rural area and get caught by the traffic police or complain by the road user? How does your company settle it?

Q14. What does the company do if the workers do not listen and follow the rule and regulation of safety awareness that apply by the company?

\subsection{Data Processing}

The data form the in-depth interviews and participants' feedback, is ensured that respondents clearly answer the questions in the interview. There is not necessary to do a word-for-word transcription during the interview session.
The question should be well guide and explain to the respondents so that it could reduce misunderstanding. The response data will be recorded as crucial data then summarize and analyses.

\subsection{Data Analysis}

The data analysis is divided into two type that are taken into consideration which are confirmatory and exploratory data analysis. Confirmatory analysis is a statistical technique that verifies the factor structure of a set of observed variables. Confirmatory analysis test the hypothesis between observed variables and the underlying latent constructs exists. In this analysis, the data are used for several statistical tests to determine that the perfectivity of the model fits to the data. Constraints may be imposed to force the model to be consistent with the theory. The constraints that the researcher had imposed on the model are inconsistent with the sample data will cause the statistical tests results of model fit into poor fit and the model will be rejected. It may be due to some items measuring multiple factors if the fit is poor. It could also be that the data within a factor are more related to each other than others [17].

Besides that, exploratory data analysis is an approach for data analysis that employs a variety of techniques. Descriptive statistics generated to help for more understanding about the data. Data visualization used to examine the data in terms of graphical format. It is to obtain additional insight regarding the messages within the data.

\subsection{Validity Test}

Validity test is a test that measure what it is not valid or invalid [18-23]. It provides adequate coverage of the investigative guiding to the study. Hence, a list of questions is prepared for the selecting respondents with that are working with the logistics industry. In the questionnaire, it focuses on the awareness of safety for trucks and the factor of safety awareness for trucks with the companies in the logistics industries.

\section{RESULT AND DISCUSSION}

There were 3 companies from KL had participated in the interview. The information of the participants is shown in Table 1.

\begin{tabular}{|c|c|c|c|}
\hline & Participant 1 & Participant 2 & Participant 3 \\
\hline Name & Lim Teong Kwee & Mr William & Lee Kim Leng \\
\hline Age & 60 years old & 40 years old & 57 years old \\
\hline Company & Kean Guan (Lim Kee) sdn bhd owner & Manager of Tesco or Cold Chain storage & $\begin{array}{c}\text { Director of Tiong Joo Trading } \\
\text { Sdn Bhd }\end{array}$ \\
\hline Experience & 20years trucking experiences & 10years experience & 20years experience \\
\hline
\end{tabular}

\subsection{Section 1}

3.1.1 How does the cost efficiency affect the safety performance in the logistics industry in Peninsular Malaysia? 
The three respondents mention that their employees must wear a suitable uniform such as long pants and safety shoes to work, follow the company rule, the safety sign published and Buku Pemanduan Pemandu. With this, the employees in those companies could avoid injuries if their employees follow the rule and regulations provided by them so that it could save the company a lot of money. When there are too many accidents occur in the company, OSHA wills penalties the company. While the safety issues are too often, OSHA can shut the operation down. Therefore, a Safety Manager is important and responsible for safety and on-going safety training. Not only that, two of the respondents also mention that they have their maintenance for trucks based on Kilometer run, contract and maintenance repair with the manufacturer. While for the other one, their company will send the truck to service maintenance every quarter of year. Maintenance is important due to save money such as is the trucks break down on the road, the delivery of the goods will stop in action and it can be costly for man hours, customer service and accidents.

\subsubsection{What is the relationship between surrounding environment and the awareness of road safety?}

Three respondents respond that the weather in Malaysia is too hot, therefore their trucks provided tinted glasses for their employees so that the trucks are cool and prevent their employees' eyes impact by the sunlight. Besides that, in the rural area, the respondents have set a limited speed for their drivers such that $40 \mathrm{~km} / \mathrm{hrs}$ as it is very dangerous to speed in the rural area where the road is narrow and high wind causes the trucks unstable. While for the highway, one of the respondent has tighten up the accelerator until a certain limit that is $80 \mathrm{~km} / \mathrm{hrs}$ where the drivers are unable to speed. Therefore, the surrounding environment will affect the awareness of road safety.

\subsubsection{How does the customer reliability affect the safety performance in the logistics industry in Peninsular Malaysia?}

The respondents respond that if they have any delays in delivering the goods, they will inform the customer due to the reasons so that the customer able to understand and the supervisor or manager will take the responsibility. This is to prevent the truck driver speeding to rush for the delivery and will cause accidents. In additions, if the customer wants to change the schedule of delivery, they must inform the company 3 days before the delivery date according to the Services Level Agreement. Thus, the company able to prepare for the delivery on time and won't be rushing.

\subsection{Section 2}

Table 2 presents the collected data during the interview session and about 14 questions were questioned to the 3 participants regarding the awareness of road safety for trucks transportation in Peninsular Malaysia.

Table 2. Similarity of Thoughts

\begin{tabular}{|c|c|c|c|}
\hline No. & Participant 1 & Participant 2 & Participant 3 \\
\hline Q1 & $\begin{array}{l}\text { Yes, can prevent accident to } \\
\text { happen. }\end{array}$ & $\begin{array}{l}\text { Yes, there are several reasons, Driver Safety, } \\
\text { Asset Safety, Cargo Safety, Image }\end{array}$ & $\begin{array}{l}\text { Yes, if not it will take away a life in an } \\
\text { accident. }\end{array}$ \\
\hline Q2 & $\begin{array}{l}\text { Yes, provide training for each } \\
\text { employee in the company and } \\
\text { they are aware of what they } \\
\text { are working. }\end{array}$ & $\begin{array}{l}\text { Yes. We provide every two times in a year } \\
\text { and provide defensive driving skills. All } \\
\text { drivers are aware of it to join the training and } \\
\text { evaluation of the training will be provided to } \\
\text { the driver. }\end{array}$ & $\begin{array}{l}\text { Yes, when hire a new driver, I will follow the } \\
\text { new driver to deliver the good and instruct him } \\
\text { where the customer place located. I will notice } \\
\text { the driver action by taking care of their safety } \\
\text { and make sure they fulfill the safety condition. }\end{array}$ \\
\hline Q3 & $\begin{array}{l}\text { Perform audit by checking the } \\
\text { workers whether they are } \\
\text { applying it. }\end{array}$ & $\begin{array}{l}\text { Perform audit that could be monthly audit or } \\
\text { quarterly audit (try to check the workers } \\
\text { whether they are applying the skills that } \\
\text { given to the driver during the training after } \\
\text { coming back from transportation activity) }\end{array}$ & $\begin{array}{l}\text { Our company will make an audit by month. } \\
\text { Audit is to check the workers whether they are } \\
\text { applying the skill during the first time when I } \\
\text { taught them. }\end{array}$ \\
\hline Q4 & $\begin{array}{l}\text { Yes, follow the law and } \\
\text { regulation by the government }\end{array}$ & $\begin{array}{l}\text { Yes. It is a must to follow the law and } \\
\text { regulation. Government (SPAD), JPJ and } \\
\text { Transport association will take action if they } \\
\text { are not following the law and regulation. }\end{array}$ & $\begin{array}{l}\text { Yes, we must the law and regulation because } \\
\text { license is given by the government. } \\
\text { Government department such as SPAD, JPJ } \\
\text { will always having a roadblock to check the } \\
\text { truck whether fulfill the condition or not. }\end{array}$ \\
\hline Q5 & $\begin{array}{l}\text { First attitude, the entire } \\
\text { employee must wear safety } \\
\text { shoes, long pants, follow rule } \\
\text { and Buku Pemanduan } \\
\text { Pemandu. If any issues } \\
\text { happen, the company will } \\
\text { show the letter that the driver } \\
\text { had cost and after explaining } \\
\text { the company will give the } \\
\text { warning letter or terminate } \\
\text { them due to the reason. }\end{array}$ & $\begin{array}{l}\text { First attitude, we get all the employee } \\
\text { follows the company Standard Operating } \\
\text { Procedure (SOP). Wear the uniform and } \\
\text { safety shoes, follow the safety sign } \\
\text { publishes, and follow rule and Buku } \\
\text { Pemanduan Pemandu. If any issues happen, } \\
\text { the company will show the letter that the } \\
\text { driver had cost and after explaining they will } \\
\text { only give the warning letter or terminate } \\
\text { them. }\end{array}$ & $\begin{array}{l}\text { Safety-first attitude is making sure they all } \\
\text { follow the company Standard Operating } \\
\text { Procedure (SOP). Company's safety rules, } \\
\text { wear safety shoes and uniform. I will remind } \\
\text { my worker by showing the sign board in every } \\
\text { section and corner. }\end{array}$ \\
\hline Q6 & $\begin{array}{l}\text { Driver need to inform to the } \\
\text { supervisor that they are in a } \\
\text { problem that is unexpected } \\
\text { delay due to heavy rain or } \\
\text { traffic jam. Supervisor will } \\
\text { inform customer and the } \\
\text { supervisor will take the }\end{array}$ & $\begin{array}{l}\text { Driver need to inform to the offices and } \\
\text { supervisor that there is an unexpected delay } \\
\text { due to heavy rain or traffic jam. Supervisor } \\
\text { will inform customer and the supervisor will } \\
\text { take the responsibility. }\end{array}$ & $\begin{array}{l}\text { If this case happens due to unexpected delays, } \\
\text { the driver needs to inform our office. } \\
\text { Supervisor will inform our customer that we } \\
\text { meet an unexpected delay, hope them can } \\
\text { forgive. }\end{array}$ \\
\hline
\end{tabular}




\begin{tabular}{|c|c|c|c|}
\hline & responsibility. & & \\
\hline Q7 & $\begin{array}{l}\text { Yes, we strictly stick to the } \\
\text { Services Level Agreement } \\
\text { which known as the S and A }\end{array}$ & $\begin{array}{l}\text { Yes, because they must strictly stick to the } \\
\text { services level agreement. }\end{array}$ & $\begin{array}{l}\text { Yes, they must strictly stick to the services } \\
\text { level agreement. }\end{array}$ \\
\hline Q8 & $\begin{array}{l}\text { Usually we perform our } \\
\text { maintenance based on } \\
\text { Kilometer run, contract and } \\
\text { maintenance repair with the } \\
\text { manufacturer. }\end{array}$ & $\begin{array}{l}\text { Based on Kilometer run, contract and } \\
\text { maintenance repair with the manufacturer. If } \\
\text { the trucks are not maintained properly, there } \\
\text { will be a lot of where and there problem. }\end{array}$ & $\begin{array}{l}\text { Our Company will send the truck to service } \\
\text { maintenance every quarter of year. We will } \\
\text { make sure the engine and tyre are all in good } \\
\text { condition. We also have maintenance before } \\
\text { going to the vehicles inspection. }\end{array}$ \\
\hline Q9 & $\begin{array}{l}\text { Yes, if the transportation road } \\
\text { journey is long. }\end{array}$ & $\begin{array}{l}\text { Yes. We will hire normally when the } \\
\text { distances are more than } 8 \text { hours. }\end{array}$ & $\begin{array}{l}\text { Yes, so far, our deliver only delivers to north } \\
\text { that is Seremban and south that is Muar and we } \\
\text { located in Melaka. It might not be long distance } \\
\text { for us. Long distance it considers at least } 8 \\
\text { hours. We also hire a co-driver even short } \\
\text { distance because they need to carry the goods } \\
\text { to the customer industry and two is better than } \\
\text { one that can make the work more efficiency } \\
\text { driving. }\end{array}$ \\
\hline Q10 & $\begin{array}{l}\text { Our trucks have the tinted } \\
\text { glasses. }\end{array}$ & $\begin{array}{l}\text { Yes. Our trucks already have the tinted } \\
\text { glasses because it is too hot inside and } \\
\text { outside. The tinted glasses are follow against } \\
\text { the rule of JPJ that is flat thickness of } 60 \\
\text { degree to prevent heat into the trucks. }\end{array}$ & $\begin{array}{l}\text { Yes. We have already installed the tinted } \\
\text { glasses in the truck because it is too hot inside } \\
\text { and prevent the eyes impact by the sunlight. }\end{array}$ \\
\hline Q11 & $\begin{array}{l}\text { We do not allow driver to use } \\
\text { smartphone while driving. } \\
\text { However, listening to radio is } \\
\text { allowed as we are human } \\
\text { being. }\end{array}$ & $\begin{array}{l}\text { Some company provided GPS in trucks. Our } \\
\text { company does not allow GPS in the phone } \\
\text { and smartphone are not allowed to use. We } \\
\text { already fixed their GPS in the trucks and } \\
\text { driving can listen to the radio. }\end{array}$ & $\begin{array}{l}\text { We have provided the GPS in the truck and we } \\
\text { are not allowed driver use the smartphone GPS } \\
\text { and driver can listen to the radio while driving }\end{array}$ \\
\hline Q12 & $\begin{array}{l}\text { The company had set a } 40 \\
\text { kilometer per hour when } \\
\text { entering the rural area as it is } \\
\text { dangerous to drive fast. }\end{array}$ & $\begin{array}{l}\text { Our company had tight up the accelerator } \\
\text { until a certain limit that is } 80 \mathrm{~km} / \mathrm{hrs} \text {. While } \\
\text { for the Jalan Kampong that known as rural } \\
\text { area, the company set at a } 40 \mathrm{~km} / \mathrm{hrs} \text {. }\end{array}$ & $\begin{array}{l}\text { Yes, if the rural areas seldom mention the } \\
\text { speed limit, we will set the driver speed limit. } \\
\text { We will set the speed about } 40 \mathrm{~km} / \text { hour to the } \\
\text { driver }\end{array}$ \\
\hline Q13 & $\begin{array}{l}\text { When the driver being fined, } \\
\text { the driver has to pay if it is his } \\
\text { fault. }\end{array}$ & $\begin{array}{l}\text { Where the driver is being fined, the 'Saman' } \\
\text { will be send to the company. The company } \\
\text { able to check the website by looking at the } \\
\text { trucks number whether they got fined or not. } \\
\text { Driver must pay or deduct from the driver's } \\
\text { salary. If the driver resigns and the company } \\
\text { has to pay. My company will give the cause } \\
\text { letter to the driver whether to do action to the } \\
\text { driver or suspend the driver by } 6 \text { months by } \\
\text { letting the driver to do paperwork. }\end{array}$ & $\begin{array}{l}\text { If the driver is fined, we will know about it } \\
\text { because it will show the record of the JPJ } \\
\text { website. Fined will paid by the driver himself } \\
\text { as a penalty because our company have already } \\
\text { set the rule and he or she didn't follow it. }\end{array}$ \\
\hline Q14 & $\begin{array}{l}\text { Of course, we will terminate } \\
\text { the worker. }\end{array}$ & $\begin{array}{l}\text { In this case, We will immediate suspend the } \\
\text { workers, issues cost letter, conduct domestic } \\
\text { inquiry if the case is very serious until } \\
\text { termination. }\end{array}$ & $\begin{array}{l}\text { Immediate suspension, issues cost letter, } \\
\text { conduct domestic inquiry if the case is very } \\
\text { serious until termination. }\end{array}$ \\
\hline
\end{tabular}

There are 14 points for similarity that can classify into 5 categories namely Driver Behaviour, Attitude and Human Error, Surrounding Environment, Government Legislative as well as Distracted Driving and Tracking. These points help others or future study in developing or

Table 3. Classification of the awareness of road safety for trucks transportation in Peninsular Malaysia

\begin{tabular}{|c|c|c|}
\hline $\begin{array}{l}\text { Interview } \\
\text { Question }\end{array}$ & Similarities & Categories \\
\hline $\mathrm{Q} 1$ & $\begin{array}{l}\text {-Yes, safety is very important } \\
\text {-Prevent accident }\end{array}$ & Driver behaviour, attitude and human error \\
\hline Q2 & -Provide training to the worker & Driver behaviour, attitude and human error \\
\hline Q3 & -Perform audit to the driver (check the driver skill) & Driver behaviour, attitude and human error \\
\hline Q4 & -Follow the law and regulation & Government Legislative \\
\hline Q5 & $\begin{array}{l}\text {-Standard Operating Procedure (SOP). } \\
\text {-wear safety shoes, long pants, follow rule and Buku } \\
\text { Pemanduan Pemandu } \\
\text {-If any issues happen, the company will show the letter } \\
\text { that the driver had cost }\end{array}$ & Government Legislative \\
\hline Q6 & $\begin{array}{l}\text {-inform to the offices and supervisor. -supervisor will } \\
\text { inform customer }\end{array}$ & Surrounding environment \\
\hline Q7 & -services level agreement. & Government Legislative \\
\hline Q8 & -Based on Kilometre run & Government Legislative \\
\hline Q9 & -Hire co-driver if long distance & Driver behaviour, attitude and human error \\
\hline Q10 & -Tinted glass to prevent hot & Distracted driving \\
\hline Q11 & $\begin{array}{l}\text {-Not allowed smartphone GPS } \\
\text {-Already provide fixed GPS in the truck }\end{array}$ & Tracking \\
\hline Q12 & -Will sets the speed around $40 \mathrm{~km} / \mathrm{hour}$ & Government Legislative \\
\hline
\end{tabular}

constructing as for the awareness of road safety for trucks transportation in Peninsular Malaysia. The point of similarity and the categories is shown in Table 3 . The answers from this table are based on interview questions. 


\section{\begin{tabular}{cl}
\hline Q13 & $\begin{array}{l}\text {-Driver } \\
\text {-Able to }\end{array}$ \\
\hline Q14 & -Termin \\
CONCLUSION
\end{tabular}}

Based on the obtained interview information, the hypotheses of this study are achieved whereby the speed performance results the safety procedure, the company greediness for small gains or profits results the awareness of safety their employees, the government's legislation punishment is not very effective and also the employees lack of understanding on safety precaution results in their own risk. Thus, the awareness of safety for road transportation is very important and need to consider from the aspect of Driver Behaviour, Attitude and Human Error, Surrounding Environment, Government Legislative as well as Distracted Driving and Tracking. Therefore, every trucks company need to manage well their safety management to prevent any accident to happen in and out the company. The safety manager should acknowledge that it is how dangerous if their employees do not follow the rule and regulation given by the company.

\section{References}

1. Organisation, I. C. D., 2017. Road, s.1.: s.n.

2. Fai, L. C. (2015). Miros statistics say human error causes $80 \%$ of traffic accidents. Retrieved from http://www.thesundaily.my/news/1333889

3. CARRS-Q. (2015). A Fact Sheet of the Centre for Accident Research \& Road Safety. Speeding.

4. Jaroszweski, D. (2014). The influence of rainfall on road accidents in urban areas: A weather radar approach. Travel Behaviour and Society, 1(1).

5. Sultan, Z., Ngadiman, N. I., A.Kadir, F. D., Roslan, N. F., \& Moeinaddini, M. (2016). Factor Analysis Of Motorcycle Crashes In Malaysia. Journal of the Malaysian Institute of Planners, 135-146.

6. Bernama. (2016). Transport minister: Mobile phone the main cause of road accidents . Retrieved from the malaymail online: http://www.themalaymailonline.com/malaysia/articl e/transport-minister-mobile-phone-the-main-causeof-road-accidents

7. Khor, S. (2015). WEF Ranks Malaysia The World's 8th Most Efficient Government. But Are We Really Worthy? Retrieved from says: http://says.com/my/news/malaysia-ranks-as-8thmost-efficient-government

8. Wahida Ameer Batcha, Norlen Mohamed, Nurul Kharmila Abdullah, Muhammad Fadhli Mohd Yusoff, Sharifah Allyana Syed Mohamed Rahim, Mohd Shah Mahmood. (2012). Alcohol and Drug Use Among Fatally Injured Drivers in Urban Area of Kuala Lumpur. Malaysia.: Malaysian Institute of Road Safety Research (MIROS).

9. Nina Dragutinovic \& Divera Twisk. (2005, December ). Use of mobile phones while driving effects on road safety. Retrieved from
Driver behaviour, attitude and human error

Driver behaviour, attitude and human error

politieacademie:

https:/www.politieacademie.nl/kennisenonderzoek/ kennis/mediatheek/PDF/76586.pdf

10. Villines, Z. (2016, May 9). Listening to Radio Can Lead to Distracted Driving. Retrieved from GoodTherapy.org: http://www.goodtherapy.org/blog/listening-to-theradio-can-lead-to-distracted-driving-0509161

11. Wallace, B. (2003, September 24). Driver distraction by advertising: genuine risk or urban myth? Retrieved from http://cogprints.org: http://cogprints.org/3307/1/driverdistractionarticle.p df

12. Minhat, H. (2015). An Overview On The Methods Of Interviews In. International Journal of Public Health and Clinical Sciences.

13. Gill, P., Stewart, K., Treasure, E., \& Chadwick, B. (2008). Methods of data collection in qualitative research: interviews and focus groups. British Dental Journal 204, 291 - 295.

14. Wahab, S.N., Sham, R., Hussin, A.A.A, Ismail, S., \& Rajendran, S.D. (2018). Urban Transportation: An Analysis on Bike Sharing Usage in Klang Valley. International Journal of Supply Chain Management, 7(5), pp. 470-476.

15. Battaglia, M. P. (2008). Nonprobability Sampling. Encyclopedia of survey Research Methods.

16. Sham, R., Wahab, S.N., Anuar, M.M., Tong, W.H. \& Yap, J.T. (2019). Safety Indicator for Taxi Users in Urban Area. International Journal of Supply Chain Management, 8(2), pp. 1035-1041.

17. Diana D. Suhr, P. (n.d.). Exploratory or Confirmatory Factor Analysis? Statistics and Data Analysis, 200-31.

18. Sham, R., Wahab S.N., \& Hussin, A.A.A. (2018). Smart Trolley Apps: A Solution to Reduce Picking Error. International Journal of Supply Chain Management, 7(5), pp. 294-302.

19. Teo, A.C., Tan, G.W.H., Cheah, C.M., Ooi, K.B \& Yew, K.T. (2012). Can the Demographic and Subjective Norms Influence the Adoption of Mobile Banking?', International Journal of Mobile Communications, Vol. 10 No. 6, 578-597.

20. Wahab, S.N., Sayuti, N.M. \& Talib, M.S.A. (2018). Antecedents of Green Warehousing: A Theoretical Framework and Future Direction. International Journal of Supply Chain Management, 7(6), 382388.

21. Teo, A.C., Tan, G.W.H., Ooi, K.B, Hew, T.S and Yew, K.T. (2015) 'The Effects of Convenience and Speed in M-Payment Usage', Industrial Management and Data Systems, Vol. 115 No. 2, 311-331

22. Rajendran, S.D., Wahab, S.N, Ling, Y.W., and Yun, L.S. (2018). The Impact of Logistics Services On the E-Shoppers' Satisfaction, International Journal of Supply Chain Management, 7(5), pp. 461-469.

23. Wahab, S.N., Lay, Y.F., Koay, W.L., \& Hussin, A.A.A, (2019). Usage of Pedestrian Bridge among 
the Urban Commuters in Kuala Lumpur.

10.1504/IJOR.2021.10019276.

International Journal of Operational Research, DOI: 